\title{
Kristen kirke i et pluralistisk samfund
}

\author{
En ny kurs for nordisk folkekirkelig ekklesiologi
}

\author{
Lektor, ph.d. \\ Jeppe Bach Nikolajsen \\ Menighedsfakultetet i Aarbus, Menighedsfakultetet i Oslo
}

\begin{abstract}
Due to significant cultural and religious changes in the Western world, a significant theological debate has recently taken place. As Western societies are becoming increasingly pluralistic, an increasing number of theologians debate the consequences of this for the Christian church and for Christian theology. Against this background, the article demonstrates the existence of a monolithic unity of church and society in Denmark, Norway and Sweden from the sixteenth century up until the early twentieth century. Next, the article presents some empirical and theological arguments for the need for a stronger articulation of the church as a distinct social entity within late-modern pluralistic Nordic societies. Finally, the article discusses the notion of the embodiment of the church, suggesting that this idea should be central in a development of a Nordic folk church ecclesiology that points to the future.
\end{abstract}

Keywords: Pluralistic society - freedom of religion - ecclesiology - state church - folk church - Hans Lassen Martensen - Johan Alfred Eklund - Ola Sigurdson.

\section{Introduktion}

Adskillige teologer er optaget af det faktum, at den vestlige verden befinder sig i en overgangsfase fra at udgøre udprægede monolitiske samfund til i stigende grad at være pluralistiske samfund. Disse ændringers omfang og betydning for den kristne kirke og den kristne teologi drøftes $\mathrm{i}$ en lang række artikler og bøger. ${ }^{1}$ Her anføres det ofte, at ikke blot den kristne kirke, men også den kristne teologi er i forandring. Disse drøftelser har stået på i flere årtier i internationale fagteologiske miljøer. Teologer fra forskellige lande og med forskellig konfessionel baggrund bidrager til samtalen. Nordiske forhold

1. Jeg har skitseret denne drøftelse andetsteds; se Jeppe Bach Nikolajsen, The Distinctive Identity of the Church: A Constructive Study of the Post-Christendom Theologies of Lesslie Newbigin and John Howard Yoder (Eugene: Pickwick 2015a), 3-11. 
samt lutherske teologiske indsigter har imidlertid ikke spillet nogen afgørende rolle i denne specifikke internationale debat. Denne artikel tager afsæt i nævnte drøftelse og vil påvise en særpræget sammentænkning af folk og kirke i Danmark, Norge og Sverige fra det sekstende og op i det tyvende århundrede. ${ }^{2}$ Dernæst argumenteres der for nødvendigheden af en tydeligere artikulering af en teologi om kirken som en særlig social størrelse i senmoderne pluralistiske nordiske samfund. ${ }^{3}$ Således berører artiklen en grundliggende teologisk problemstilling, som angår kirkens plads i verden, som altså så aktualiseres i henhold til de nordiske folkekirkers historie og rolle i de nordiske samfund. ${ }^{4}$ På den baggrund drøfter artiklen afslutningsvist udtrykket kirkens kropslighed som væsentlig for udviklingen af en nordisk folkekirkelig ekklesiologi, som peger ind i fremtiden.

\section{Kirke i et monolitisk samfund}

De nordiske lande er illustrative eksempler på samfund, som engang var monolitiske samfund, men som i dag er pluralistiske samfund. De nordiske lande var således monoreligiøse samfund i store dele af det sekstende til det nittende århundrede. ${ }^{5}$ I det følgende skal tydeliggøres en særpræget sammentænkning af folk og kirke i Danmark, Norge og Sverige i denne periode, hvor man først finder statskirker og siden folkekirker. ${ }^{6}$

2. I denne artikel giver jeg kun eksempler fra de skandinaviske lande, selvom jeg mener, at samme forhold gør sig gældende for alle de nordiske lande.

3. Den britiske teolog Nigel Biggar skriver: "[Integrity] is not the same as distinctiveness. One is a virtue; the other is an accident of history"; se Nigel Biggar, Behaving in Public: How to Do Christian Ethics (Grand Rapids: Eerdmans 2011), 8. Med Biggars ord er jeg i denne artikel mere optaget af kirkens distinkthed end dens integritet. Jeg stiller mig dog kritisk over for Biggars begrebsdefinitioner og forstår således begrebet distinctiveness anderledes end han; se Nikolajsen (2015a), 15-16.

4. Når jeg i denne artikel refererer til begrebet kirke, anerkender jeg hermed kun en konkret, synlig, erfarbar kirke bestående af mennesker af kød og blod, og jeg opererer således ikke med en skelnen mellem en synlig og en usynlig kirke.

5. Flere forskere har imidlertid påpeget, at kristianiseringen af Europa på reformationstiden var overfladisk; se eksempelvis Anton Wessels, Europe: Was it Ever Really Christian? (London: SCM 1994), 96-160; se også Jean Delumeau, Le catholicisme entre Luther et Voltaire (Paris: Presses Universitaires de France 1971), 227-255.

6. Ifølge den tyske teolog Wolfgang Huber opstod folkekirkebegrebet i tysk protestantisme i begyndelsen af det nittende århundrede; se Wolfgang Huber, "Volkskirche. I. Systematisch Theologie", TRE 35 (Berlin: de Gruyter 2003), 249. Det vandt så hurtigt indpas i Norden. I Sverige og Norge har man dog formelt set haft statskirker helt op til henholdsvis år 2000 og 2014, selvom folkekirkebegrebet er 
Fra 1536 til 1849 skulle alle indbyggere i Danmark, med få undtagelser, tilhøre den lutherske statskirke. I denne periode forsøgte flere danske konger at holde anderledes troende ude af landet. Der var dåbs- og gudstjenestetvang, og man kan finde eksempler på, at den danske konge befalede, at kirketugt i sognene skulle forrettes omhyggeligt, at familiefædre dagligt skulle holde andagter i hjemmene, og at personer, der sov under prædikenen, skulle vækkes af et net slag i hovedet med en kæp. Folkets gudsfrygt og moral var et vigtigt anliggende for kongerne, da fromhed styrker rigerne, som det hed under enevælden. I det syttende århundrede retfærdiggjorde den danske teolog Hans Wandal enevælden med henvisninger til de bibelske skrifter indebærende, at kongen var intet mindre end Guds stedfortræder på jord og kun var underordnet Gud. ${ }^{7}$ Folket skulle således adlyde kongen, og kongen skulle således holde landet fri af vranglære og falske religioner. ${ }^{8}$ Senere kom statskirkeligheden dog under kraftig kritik blandt andet på grund af fremvæksten af pietismen og oplysningstidens gennembrud. ${ }^{9}$ I forbindelse med Grundlovens vedtagelse blev religionsfrihed indført, og den danske statskirke blev en folkekirke. ${ }^{10}$ Den danske biskop Hans Lassen Martensen var optaget af den danske folkekirkes nye ordning, var medlem af flere kirkekommissioner og udgav en række skrifter om dette. I sit skrift Den danske Kirkes Forfatningsspørgsmaal benytter Martensen begrebet individualitetskirken til at karakterisere den forståelse af kirken, at kun hin enkelte kan være kristen, og at det derfor giver dårlig mening at betegne et helt folk som kristent. I modsætning hertil udvikler han sin egen position, som han betegner med udtrykket folkekirken. Her betragtes det danske folk ikke blot som en tilfældig forening af enkeltindivider, men som en organisk enhed, en åndelig enhed, et stort individ med egen historie og karakter. ${ }^{11}$ Således forstået gælder den kristne tro ikke blot den enkelte, men også folket; menneskenes store fællesliv, som han kalder det (Martensen 1851, 14). I forlængelse

blevet hyppigt anvendt om Svenska Kyrkan og Den Norske Kirke langt tilbage i tiden.

7. Ovenstående jf. Martin Schwartz Lausten, Danmarks kirkehistorie (København: Gyldendal ${ }^{2} 2000$ ), 137-138, 140-141, 145-146, 163.

8. Bernt T. Oftestad, Den norske religionen. Fra øvrighetskirke til demokratisk statskirke (Oslo: Høyskoleforlaget 1998), 59.

9. Ruben Josefson, Kyrka och stat (Stockholm: Ehlins 1956), 30.

10. Ifølge den norske teolog Hallgier Elstad blev begrebet folkekirke anvendt for første gang i en dansk kontekst i 1841; se Hallgier Elstad, "Folkekyrkjeomgrebet - opphav og utvikling. Tysk og nordisk kontekst", Folkekirke nå, red. Stephanie Dietrich m.fl. (Oslo: Verbum akademisk 2015), 21-33 (25).

11. Hans Lassen Martensen, Den danske Kirkes Forfatningspørgsmaal (København: C.A. Reitzel 1851), 18, 52. 
af dette skriver han: "Saaledes udøver Kristendommen en dobbelt Virksomhed, en individuel, i hvilken den udfører sit værk med de enkelte Sjæle, hvilke den leder til Omvendelse og Genfødelse; og en social, i hvilken den opdrager folkene" (Martensen 1851, 53). Folkekirkens medlemsskare udgjorde stort set hele den danske befolkning på daværende tidspunkt, og Martensen var godt klar over, at mange af datidens folkekirkemedlemmer var såkaldt nominelle kristne. Det stillede han sig på mange måder positiv overfor. Den danske teolog Carl Immanuel Scharling refererer hans synspunkt således: "Man maa nemlig skelne mellem Kirken i videre Forstand, omfattende alle døbte, altsaa ogsaa dem, der kun i social Betydning hører til Kirken, og Kirken i snavrere Forstand, det som Konfessionen mener med congregatio sanctorum, Samfundet af de Hellige." ${ }^{2}$ Selvom Martensen fandt det rimeligt at operere med en sådan dualisme, anså han det altså som værende problematisk at indskrænke kirken til den snavre kreds udelukkende den øvrige del af kirken (Scharling 1928, 29). Derfor mente han, at traditionens og sædvanens kristendom skulle værdsættes. Han skriver således: "Kirken bestaar ligesaa vel af vordende Kristne som af dem, der er det - ligesaa vel af sådanne, som skal beredes, opdrages, dannes til Troen, som af saadanne, der allerede er troende" (Martensen 1851, 37). Han kunne derfor glæde sig over, at stort set alle nyfødte børn i kongeriget blev døbt på daværende tidspunkt. Det mente han var nyttigt: "[For dermed forudbestemmes] Individet til en bestemt Tro, ved at stille det under et helt Indgreb af sædelige og religiøse Indvirkninger, der alle sigte til at præge Viljen i en bestemt Retning” (Martensen 1851, 38; kursivering tilføjet). Så snart et barn var blevet døbt, ville kirken nemlig stå klar med et omfattende katekumenat, som ville opdrage i den nyvundne tro. Martensen kunne gå så langt som til at mene følgende: "[Hele folket og hele samfundet må] underordne sig under Guds vilje, hans Ord, og udtrykke denne underordning i sine Love og Institutioner" (citeret i Scharling 1928, 24). Derfor havde han heller ikke problemer med at betragte en stat som kristen, når ellers en sådan stat fandt sit religiøst-etiske grundlag i kristendommen (Scharling 1928, 23). Og derfor var en enhed mellem stat og kirke et ganske naturligt forhold for ham. Følgelig anførte han, at først når en kirke har etableret sig som en kristen statskirke, har den nået sit fulde mål i verden (Martensen 1851, 86). ${ }^{13}$ Alt

12. Carl I. Scharling, H.L. Martensen. Hans tanker og livssyn (København: P. Haase og Søns Forlag 1928), 29 (kursiveringer originale).

13. For en yderligere behandling af Martensens forfatterskab, se Skat Arildsen, Biskop Hans Lassen Martensen (København: Gad 1932); Else Rovsing Pedersen, Biskop Martensens opfattelse af kirkens stilling til de sociale sporgsmål $i$ sidste halvdel af det 19. århundrede $i$ Danmark (København: Arken-Tryk 1983); Jon Stewart (red.), Hans 
dette komplementeres af den danske teolog Nikolai Frederik Severin Grundtvigs udtalte forkærlighed for Danmark. Den danske teolog Hal Koch skriver eksempelvis, at ifølge Grundtvig var Danmark tiltænkt ikke blot en afgørende rolle i verdenshistorien, men også i Guds store planer med verden. Derfor vil Gud aldrig kunne opgive Danmark og vil altid stå på landets side i krige. Ifølge Koch vil man kunne "blive ved med at anføre Citater, der synes at vidne om en ganske urimelig Forgudelse af alt, hvad der er dansk", om det være sig naturen, historien, folket eller sproget. Ifølge Koch oplevede Grundtvig ofte, at hans øjne fyldtes med tårer, når han fik sine syner om landets storhed, og så måtte han synge, ja, lovsynge og berømme alt dansk..$^{14}$ Selvom der eksisterede andre teologiske stemmer med andre betoninger i det sekstende til det nittende århundrede i Danmark, har jeg ovenfor antydet en udbredt sammentænkning af folk og kirke, som altså kan identificeres i Danmark i denne periode. ${ }^{15}$

Når det gælder Sverige, udgjorde dette land ligesom Danmark et monoreligiøst samfund med dåbs- og gudstjenestetvang i store dele af det sekstende, syttende, attende og det nittende århundrede. ${ }^{16}$ Gennemførelsen af reformationen strakte sig fra et rigsdagsmøde i 1527 og århundredet ud. Med den svenske enevælde, som blev indført i 1682, fulgte et stærkt fokus på uniformitet og et teokratisk syn på kongemagten. ${ }^{17} \mathrm{Om}$ religionsfriheden, som først blev indført noget senere, skriver den danske historiker Karin Lützen: "Frem til 1860 var det forbudt at bekende sig til nogen anden religion end den evangelisk-lutherske. Med dissenterlovene fra 1860 og $1873 \mathrm{blev}$ det ganske vist tilladt for svenske statsborgere at konvertere til den katolske kirke og andre statsligt anerkendte religionssamfund, men det var forbundet med strenge restriktioner at træde ud af den svenske statskirke." ${ }^{18}$ Den svenske teolog Johan Alfred Eklund, som blev født i 1863 , betegnes ofte som en fremtrædende svensk folkekirkeideo-

Lassen Martensen. Theologian, Philosopher and Social Critic (København: Museum Tusculanum Press 2012); Stephen Backhouse, Kierkegaard's Critique of Christian Nationalism (Oxford: Oxford University Press 2011).

14. Hal Koch, Grundtvig (København: Gyldendal 1943), 141-142.

15. Det skal retfærdigvist nævnes, at Grundtvig havde en ganske anderledes ekklesiologi end Martensen og eksempelvis ikke forfægtede en statskirke. Efter min mening findes der teologiske ressourcer hos Grundtvig, som kan være til hjælp for kirken eksisterende i et pluralistisk samfund.

16. Første gang begrebet folkekirke blev anvendt i en svensk kontekst var i 1876; se Elstad 2015, 27.

17. P.G. Lindhardt, Den nordiske kirkes historie (København: Nyt Nordisk Forlag Arnold Busck 1945), 125-136, 186-188.

18. Karin Lützen, anmeldelse af Yvonne Maria Werners Kvinnlig motkultur och katolsk mission i HT 104 (2005), 288-289. 
log. ${ }^{19}$ Hos Eklund bliver både land og folk tolket religiøs. Han forankrer dette bibelteologisk ved at påpege, at Israel ikke blot var en etnisk, men også en geografisk størrelse. Den svenske teolog Ragnar Ekström udtrykker Eklunds synspunkt således: "Landet kommet at uppfattas som en del av Israel och endast i landet kan israelitiskt liv i dess fulla bemärkelse verkligen levas." ${ }^{20}$ Ikke blot det svenske land, men også det svenske folk tolkes som nævnt religiøst. Elstad skriver:

Sverige bliver forstått som Guds utvalde folk. Eklund er overtydd om at Gud har ei særleg oppgåve for det svenske folket, slik han hadde for Israel. Denne nasjonalt inspirerte kyrkjetenkinga kjem tydeleg til uttrykk i Eklunds salme 'Fädernas kyrka' frå 1909. Kyrka og nasjonen er her kopla tett saman (Elstad 2015, 27).

I en prædiken fra 1894 kan Eklund slet og ret anføre, at det svenske folk er Guds folk. Dette folk har et folkehjerte, som Gud kan tale til, og som er skabt til at være en tavle, i hvilken Gud kan mejsle sin lov (Sundberg 1982, 57). I den førnævnte salme, Fädernas kyrka, som på et tidspunkt blev fjernet fra den svenske salmebog, da mange fandt den for nationalistisk, hedder det, at fæd rekirken omfavner fædrelandet, fra strand til strand, og at det derfor ikke er uden grund, at korset er afbilledet på fædrelandsflaget. Som det israelitiske folk havde fået givet et land, har det svenske folk fået givet et land. Og som det israelitiske folk havde fået givet en konge, har det svenske folk fået givet en konge (Sundberg 1982, 58-59). I bøger, prædikener og salmer finder man således hos Eklund en særpræget sammentænkning af folk og kirke, og i forlængelse af det knyttes folk, kirke og land sammen i en særpræget kristen nationalisme.

Vendes blikket mod Norge, der som bekendt var en del af kongeriget Danmark-Norge fra 1536 og frem til 1814 og derefter i union med Sverige frem til 1905, skulle alle borgere også her tilhøre den lutherske statskirke i store dele af det sekstende, syttende, attende og nittende århundrede. Religionsfrihed blev ikke indført med vedtagelsen af den norske grundlov i 1814. Først med en lovgivning fra 1845 og en lang række love i anden halvdel af det nittende århundrede blev religionsfrihed gradvist indført i landet. ${ }^{21}$ Ligesom i Danmark og Sverige oplevede man i Norge i slutningen af det nittende århundrede og i

19. Karl Josef Sundberg, Fädernas kyrka. En idéhistorisk studie i folkkyrkotanken hos J.A. Eklund mot bakgrund av sekelskiftets kulturdebatt (Uppsala: Acta Universitatis Upsaliensis 1982), 11.

20. Ragnar Ekström, Gudsfolk och folkkyrka (Lund: Gleerups 1963), 11.

21. Oddbjørn Leirvik, Religionspluralisme. Mangfald, konflikt og dialog i Norge (Oslo: Pax 2007), 10-14. 
begyndelsen af det tyvende århundrede en blomstrende nationalisme, som bidrog til at folk og kirke blev betragtet som sammenfaldende størrelser. Den tysk-norske teolog Stephanie Dietrich anfører i øvrigt, at en tysk nationalisme i begyndelsen af det tyvende århundrede lagde til rette for en nationalistisk folkekirkeideologi indbefattende ønsket om en tysk rigskirke for hele det tyske folk og en arierparagraf i kirken; derfor har der ifølge Dietrich hersket en skepsis over for tanken om at ligestille folkefællesskabet med kirkefællesskabet i Tyskland siden Anden Verdenskrig. ${ }^{22}$ I det norske dokument Kirkens grunn fra 1942 blev folkekirken imidlertid et symbol på det norske folkefællesskab, og ifølge Dietrich forudsætter dokumentet "en folkekirkesituasjon der så godt som alle er døpte medlemmer av kirken, og det er en nærmest fullstendig enhet mellom folk og kirke" (Dietrich 2015, 55). I forlængelse af dette synspunkt refererer Dietrich til en anden norsk teolog, nemlig Torleiv Austad, som skriver: "Artikkelen gir tydelig inntrykk av at kirken omfatter alle, og at det norske folk er et kristent folk" (Dietrich 2015, 55).

Som det er fremgået af ovenstående har der i århundreder eksisteret en stærk tradition for en særpræget sammentænkning af folk og kirke i Norden. Skal en nordisk ekklesiologi imidlertid ikke forudsætte en kirkelig og samfundsmæssig situation, som ikke længere eksisterer, er det nødvendigt, at den ændrer karakter, hvilket da også er i færd med at ske. Som et indspil i denne forandringsproces vil jeg i det følgende præsentere nogle empiriske og teologiske argumenter for nødvendigheden af en tydeligere artikulering af en teologi om kirken som en særlig social størrelse i senmoderne pluralistiske nordiske samfund.

\section{Kirke i et pluralistisk samfund}

Den virkelighed, som er blevet beskrevet ovenfor, hører en fjern fortid til. I dag tager de nordiske samfund sig meget anderledes ud. I dag betegnes de nordiske samfund således som pluralistiske. ${ }^{23}$ De

22. Stephanie Dietrich, "Folkekirken som sanctorum communio. Innspil til nytenkning i lys av Bonhoeffers teologi og Barmenerklæringen”, Dietrich m.fil. (red.) (2015), 48-59 (53).

23. Den engelske filosof Edward Craig definerer pluralistiske samfund således: "Societies are sometimes called pluralistic, meaning that they incorporate a variety of ways of life, moral standards and religions." Se Edward Craig, "Pluralism", The Encyclopedia of Philosophy (London: Routledge 1986), 463. For en omfattende behandling af de nordiske lande som pluralistiske, se bogen Pluralisme og identitet. Kulturanalytiske perspektiver på nordiske nasjonalkirker i møte med religiøs og moralsk pluralisme, red. Jan-Olav Henriksen \& Otto Krogseth (Oslo: Gyldendal 2001). Og 
nordiske lande bliver imidlertid ofte fortsat betragtet som udpræget harmoniske og homogene samfund. Derfor er det naturligt at spørge, om det nu også er rimeligt at betegne disse lande som pluralistiske. Dertil er der at sige, at det er et faktum, at store dele af de nordiske befolkninger ikke længere er en del af de nordiske folkekirker, og at færre og færre bliver døbt og viet i disse kirker. Desuden har indvandring, individualisering og globalisering bevirket en pluralisering af de nordiske samfund. Danske Ove Korsgaard skriver derfor:

Indvandring er selvfølgelig ikke noget nyt ... Men til forskel fra tidli-
gere tider har mange tilflyttere i dag en hel anden kulturbaggrund og
en anden tro. De kommer hverken fra den nordiske eller den europæiske
kulturkreds, men fra Mellemøsten, Asien og Afrika. Og deres baggrund
adskiller sig ofte markant fra den form for danskhed og folkekirkelig
praksis, der er blevet udviklet på dansk jord i løbet af de seneste 200
år. ${ }^{24}$

Derfor kan empiriske værdiundersøgelser såsom European Value Study og World Values Surveys spore en etnisk, kulturel, etisk og religiøs pluralisering af de nordiske lande. ${ }^{25}$ Endelig er det vigtigt at bemærke, at et samfund godt kan betegnes som pluralistisk, selvom en kultur eller en religion har en hegemonisk position i et sådant samfund (jf. Schmidt 2010, 42-43). ${ }^{26}$ Følgelig anfører de tre danske teologer Svend Andersen, Niels Grønkjær og Troels Nørager: "Religionerne optræder i vore dage ofte i samfund, som kan kaldes pluralistiske. Dermed menes, at nutidens samfund ikke er præget af én eneste altdominerende livsopfattelse, men af en mangfoldighed af forskellige livsanskuelser og valg af livsstile." ${ }^{27}$

Én af konsekvenserne af pluraliseringen af de nordiske samfund er, at den kristne kirke ikke længere udgøres af alle, men kun af nogle. Efter min mening kan der altså gives empiriske argumenterer for, at

for en behandling af de nordiske lande som etisk pluralistiske, se bogen Etisk pluralisme i Norden, red. Lars Østnor (Kristiansand: Høyskoleforlaget 2001).

24. Ove Korsgaard, Folk (Aarhus: Aarhus Universitet 2013), 8-9.

25. Ulla Schmidt, "Norge: Et religiøst pluralistisk samfunn?", Religion i dagens Norge, red. Pål Ketil Botvar \& Ulla Schmidt (Oslo: Universitetsforlaget 2010), 32-37; Ulla Schmidt \& Jan-Olav Henriksen, "Religion, etikk og moral: Nye sammenhenger?", Botvar \& Schmidt (2010), 133; Lars Østnor, “Konsens eller dissens? Etikkteoretiske perspektiver på den nordiske befolkningens etikk", Etisk pluralisme $i$ Norden (Kristiansand: Høyskoleforlaget 2001), 119-121.

26. Jeg har også anført noget lignende i "Er og bør Danmark være et kristent land?" i $K D$ den 11. marts 2015 b.

27. Svend Andersen, Niels Grønkjær \& Troels Nørager, Religionsfilosofi (København: Gad 2002), 298-299 (kursiveringer originale). 
kirken i den nuværende samfundssituation må og vil betragte sig selv som en særlig social størrelse. Et eksempel på dette er, når den norske teolog Jens-Petter Johnsen om den norske folkekirke skriver:

Det er dåpen som konstituerer kirkemedlemskapet, og ikke den nasjonale tilhørigheten. Det er vesentlig å markere den prinsipielle forskjellen mellom kirkesamfunnet og borgersamfunnet. Den norske kirke er derfor ikke folkets kirke, i betydning 'det norske folk organisert som kirke', slik presten Henrik Seip uttrykte det i sitt forsvar for statskirkeordningen, like etter andre verdenskrig. Dåpen er primært et sakrament og bare sekundært et medlemskriterium. I prinsippet gjør det fellesskapet av døpte i folkekirken til et åndelig samfunn, som er av en annen art end det borgerlige samfunn. ${ }^{28}$

Det betyder, at kirken er en særlig social størrelse, og at den ofte og på forskellig vis vil være forskellig fra det omkringliggende samfund.

Ud over ovenstående empiriske argumenter for dette kan der også præsenteres teologiske argumenter for, at den kristne kirke med god grund kan og bør forstås således. Det skal vi se på nu. For det første vil jeg argumentere for, at opererer man ikke med kirken som en særlig social størrelse, løber man ind i problemer, dersom man ønsker at udvikle en ekklesiologi, som har rødder i den grundliggende teologiske tænkning om kirken, som afspejles i de nytestamentlige skrifter. For det andet vil jeg argumentere for, at kirken er kaldet til at legemliggøre et kristent fællesskab, en kristen levevis og en kristen tilværelsesforståelse, som almindeligvis ikke deles af alle i samfundet, og at dette understreger nødvendigheden af en artikulering af en teologi om kirken som en særlig social størrelse. ${ }^{29}$

Som nævnt mener jeg, at man løber ind i problemer, hvis man vil udvikle en ekklesiologi, som står i forlængelse af den teologi, som

28. Jens-Petter Johnsen, "Gud vil ha folk. Folkekirke og trossamfunn i fremtidens norske kirke”, Folkekirke nå, Dietrich m.fl (red.) (2015), 12-20 (17); Johnsens synspunkt ligger langt fra den praksis, som man siden det sekstende århundrede og langt op i det tyvende århundrede i Sverige, hvor alle nyfødte svenskere automatisk blev medlem af Svenska Kyrkan.

29. I forlængelse af ovenstående har jeg tidligere anført, at "det ligger den kristne tro fjernt ... at arbejde for en kristen statsdannelse (en slags kristen kalifat-dannelse). Det hører i stedet til den kristne tros natur at anerkende og respektere menneskers ret til at vælge et andet religiøst ståsted end det kristne. Dette anliggende er vigtigt, når et frit, åbent og tolerant samfund skal fastholdes, fremmes eller etableres. Og det betyder eksempelvis, at ikke blot den danske stat, men også den kristne kirke må bidrage til at garantere et samfund, hvor samfundsborgeres trosfrihed sikres. Følgelig er det ikke kirkens opgave at kristne et samfund, men at invitere mennesker til at blive en del af den kristne tradition og dermed få del i alle de goder, som det indebærer" (se Nikolajsen 2015b). 
afspejles i de nytestamentlige skrifter og samtidig ikke opererer med kirken som en særlig social størrelse. Hermed tre eksempler på sådanne problemer. For det første anføres det i Det Nye Testamente, "at når en person anerkender Kristus som frelser og herre, bliver denne person inkorporeret i Kristus. Mennesker bliver således en del af Kristi legeme, bliver en del af et særligt fællesskab, en ny menneskehed, et helligt samfund, et helligt præsteskab (jf. fx 1 Pet 2,9)." ${ }^{30}$ Det udtrykkes også, at kirken har et borgerskab, der ikke er af denne verden, og at kristne må adlyde Gud mere end mennesker (Fil 3,20; ApG 5,29). I det kristne fællesskab granskes og drøftes, hvad det vil sige at tilhøre Kristus. Det er efter min mening vanskeligt at fastholde en sådan ekklesiologisk betoning, hvis ikke man opererer med kirken som en særlig social størrelse. For det andet anføres det i Det Nye Testamente endvidere, "at Kristus gav sig selv hen for at rive kristne ud af den nuværende onde verden (Gal 1,4), at Kristus har løskøbt dem, der trællede under denne verdens magter (Gal 4,1-11), og at han har udfriet kristne af mørkets magt (Kol 1,13)" (Nikolajsen 2015c, 177). Dette betyder, at kirken er et eskatologisk fællesskab. Kirken er et tegn og en forsmag på gudsriget og den nye tidsalder, som er brudt ind $\mathrm{i}$ verden. Det er efter min mening også vanskeligt at fastholde en sådan eskatologisk betoning, hvis ikke man opererer med kirken som en særlig social størrelse. For det tredje anføres det i Det Nye Testamente endelig, at den kristne kirke skal søge at legemliggøre troskab over for og lydighed mod sin korsfæstede og opstandne herre. Et væsentligt aspekt ved et liv i efterfølgelse af Kristus er en villighed til at udholde forfølgelser, ligesom Jesus også selv gjorde det (jf. fx Matt 16,24-25). Det er også vanskeligt at fastholde en sådan teologisk betoning, hvis ikke man opererer med kirken som en særlig social størrelse. ${ }^{31}$ Som det fremgår af ovenstående, mener jeg, at centrale træk ved nytestamentlig ekklesiologi, eskatologi og etik implicerer, at normalsituationen for den kristne kirke er, at den ikke udgøres af alle, men kun af nogle. ${ }^{32}$ Dette kan man så vælge at ignorere, men man bør i så fald være sig bevidst, at man dermed ændrer på nogle helt

\footnotetext{
30. Jeppe Bach Nikolajsen, "Kirkens mulighed for at genvinde sig selv. John Howard Yoders antikonstantinske teologi", National kristendom til debat, red. Jeppe Bach Nikolajsen (Fredericia: Kolon 2015c), 162-163.

31. Ovenstående afsnit er inspireret af Nikolajsen (2015c); her kan således findes en større udfoldelse af disse aspekter.

32. Det er i øvrigt også bemærkelsesværdigt, at metaforer såsom salt og lys, som anvendes om kirken i Bjergprædikenen, forudsætter, at kirken udgør en minoritet (jf. Matt 5,13-16).
} 
fundamentale aspekter af og strukturer i den teologiske tænkning om kirken, som blev udviklet i de tidlige kristne menigheder. ${ }^{33}$

I tillæg til ovenstående argumenter, eksisterer der også andre gode teologiske argumenter for nødvendigheden af en artikulering af en teologi om kirken som en særlig social størrelse. Efter min mening har kirken nemlig et kald til at legemliggøre et kristent fællesskab, en kristen levevis og en kristen tilværelsesforståelse, som almindeligvis ikke deles af alle i samfundet. Når det gælder kirkens kald til at legemliggøre et kristent fællesskab, er det værd at bemærke, at udgangspunktet for den norske teolog Harald Hegstads bog Den virkelige kirke er, at kirken er et fællesskab af mennesker. ${ }^{34}$ Kirken består af mennesker, tilmed af en bestemt gruppe mennesker, nemlig kristne. I forlængelse heraf refererer Hegstad til, at det græske ord for kirke, $e k$ klesia, betyder folkeforsamling, at kirken i den apostoliske trosbekendelse betegnes som sanctorum communio, og at kirken i den augsburgske bekendelse karakteriseres som congregatio sanctorum (Hegstad 2009, 17-18). Kirken består altså ifølge disse bekendelser ikke af alle $i$ et samfund, men udgøres af en bestemt gruppe mennesker. Når det gælder kirkens kald til at legemliggøre en kristen levevis, er det oplagt at påtænke Bjergprædikenen, som udgør en vigtig ressource for en forståelse af denne levevis. Her fremgår det eksempelvis, at kristne skal tale sandfærdigt, skal værne om ægteskabet, ikke skal gøre gengæld, ikke skal samle sig skatte og ikke skal bekymre sig om dagen i morgen. Kirken består altså af mennesker, som ikke er kaldet til at leve et hvilket som helst liv. ${ }^{35}$ Også det nytestamentlige begreb koinonia belyser den levevis, som kristne er kaldet til legemliggøre. Dette begreb giver udtryk for et fællesskab i den lokale menighed, som implicerer gensidig omsorg (1 Kor 12,26; Rom 15,26) og gensidig

33. Den tyske teolog Wolfhart Pannenberg vil efter min mening også finde dette problematisk; se Wolfhart Pannenberg, Systematische Theologie I (Göttingen: Vandenhoeck \& Ruprecht 1988), specielt kapitel 1 og 4; se også Wolfhart Pannenberg, Wissenschaftstheorie und Theologie (Frankfurt: Suhrkamp 1973). Selvom Pannenberg er stærk kritisk overfor en åbenbaringspositivisme - en immuniseret teologi, som kun forlader sig på et snævert skriftprincip - mener han alligevel, at de bibelske skrifter bør tages alvorligt som normative teologiske kilder.

34. Harald Hegstad, Den virkelige kirke. Bidrag til ekklesiologien (Oslo: Tapir akademisk forlag 2009), 17-18.

35. Ifølge Martin Luther var formålet med Bjergprædikenen ikke at vække syndserkendelse hos mennesker, men den var tiltænkt som en etisk vejledning for kristnes tilværelse i verden. Luther kan derfor skrive: "Kristus holder udelukkende sin prædiken for sine kristne og vil undervise dem i, hvilken slags mennesker de skal være”. Se Martin Luther, Wochenpredigten über Matthäus 5-7 (WA 32,388,34-35) (egen oversættelse). 
kærlighed (Joh 13,34-35). ${ }^{36}$ Kirken består altså af en bestemt gruppe mennesker, som almindeligvis ikke udgør alle i et givent samfund, og som er kaldet til at udleve en levevis, som det ikke nødvendigvis er alle, der ønsker at udleve. Når det gælder kirkens kald til at legemliggøre en kristen tilværelsesforståelse, argumenterer den norske teolog Knut Alfsvåg for, at kristen teologi må anskues som et arbejde med “å fortolke og presisere egenarten i den kristne guds- og åpenbaringsforstålse, slik at det særpregede ved den kristne tro og det kristne budskap blir tydelig både $\mathrm{i}$ et historisk og et aktuelt perspektiv. I dette ligger en ambisjon om ... å ivareta den partikulære åpenbaringens pretensjon av å formidle universelt sann virkelighetsforståelse. Det kan bare gjøre gjennom en kritisk dialog med alternative kriterier for hva som er sant.. ${ }^{37}$ Han anfører endvidere:

Kristen tro er ... forankret i konkrete begivenheter som fant sted i en bestemt historisk kontekst, samtidig som den forstår disse begivenhetene som guddommelig åpenbaring som viser oss sannheten om verden og oss selv. Sakssvarende kristen teologi vil derfor forstå seg selv som meditasjon over og gjennomtenkning av inkarnasjonens mysterium. I dette arbeidet vil den måtte forholde seg kritisk til mange tenkere og tankeretninger både i fortid og nåtid, og slik kalle til motsigelse. Det er som det skal være; tenkning forankret i Guds åpenbaring av seg selv kan ikke uten videre vente å finne forståelse på grunnlag av tenkning med et helt annet utgangspunkt. Dette innebærer imidlertid ikke at kristen tenkning gir avkall på kravet om universalitet og allmenn begrunnbarhet (Alfsvåg 2015, 212).

Ovenstående teologiske perspektiver viser, at det er rimeligt at betragte kirken som bestånde af en bestemt gruppe mennesker, som er kaldet til at legemliggøre et kristent fællesskab, en kristen levevis og en kristen tilværelsesforståelse, som almindeligvis ikke deles af alle $\mathrm{i}$ samfundet. ${ }^{38}$

36. Jf. Jeppe Bach Nikolajsen, "Den missionale kirke i et pluralistisk samfund", Missional kirke i et pluralistisk samfund, red. Jeppe Bach Nikolajsen (Fredericia: Kolon 2015), 128.

37. Knut Alfsvåg, "Gudsåpenbaring og virkelighetsforståelse. Kristen åpenbaringsteologi i dag”, DTTK 42 (2015), 203.

38. Jeg har tidligere givet en mere uddybende præsentation for behovet for en tydeligere artikulering af kirkens kald til at legemliggøre et kristent fællesskab, en kristen levevis og en kristen tilværelsesforståelse; se eksempelvis min artikel "Kristen etik i et pluralistisk samfund. En ny kurs for dansk teologisk etik", DTT 79 (2016), 105-121; ovenfor har jeg fremhævet nogle andre aspekter af dette end i denne artikel. 


\section{Kirkens kropslighed i det pluralistiske samfund}

I lyset af ovenfor præsenterede empiriske og teologiske perspektiver synes det nødvendigt at operere med en tydelig partikularitet i udviklingen af en aktuel nordisk folkekirkelig ekklesiologi. Denne artikel har således anskueliggjort et nødvendigt skift i fokus fra Corpus Christianum til Corpus Christi, når en sådan ekklesiologi skal udvikles. Det kan gøres ved at betone kirken som en legemliggørelse af den kristne tradition, hvor der foregår drøftelser om denne traditions historie, egenart og udvikling. I det følgende vil jeg ikke fokusere på traditionsbegrebet, men vil drøfte udtrykket kirkens kropslighed som et væsentligt element $\mathrm{i}$ en udvikling af en nordisk folkekirkelig ekklesiologi, som peger ind i fremtiden.

Det kan for det første være gavnligt at slå fast, at kirken som Kristi legeme er et centralt aspekt af ekklesiologien i Det Nye Testamente. Her anføres det, at kristne tilhører et fællesskab, som kan sammenlignes med en krop med mange lemmer, at denne krop tilhører Kristus, og at denne krops hoved er Kristus. ${ }^{39}$ Dette skaber en kristologisk forankring af ekklesiologien, og andre steder i Det Nye Testamente anføres det da også, at Kristus er i den troende, og at den troende er i Kristus. ${ }^{40}$ Kirken som Kristi krop har da også spillet en væsentlig rolle i ekklesiologisk tænkning i begyndelsen af det tyvende århundrede; eksempelvis spiller tanken en afgørende rolle for den schweiziske teolog Karl Barth og den tyske teolog Dietrich Bonhoeffer (jf. Hegstad 2009, 25-29). De seneste år synes denne tanke at have fået en renæssance blandt teologer. ${ }^{41}$ Den svenske teolog Jan Eckerdal taler således om kroppens genkomst i nyere teologi. ${ }^{42}$

Hvad, der efter min mening er vigtigt at anføre om kroppen som udtryk for kirken, er, at det hermed tydeliggøres, at kristendom ikke handler om idealistiske abstraktioner, men indebærer et kald til at kropsliggøre det kristne evangelium. Som den britiske teolog Oliver O'Donovan skriver: "The Kingdom of God is not a mere kingdom, but it is a real kingdom ... Earthly events of liberation, rule and community-foundation provide us with partial indications of what

39. Rom 12,4-8; 1 Kor 12,27; Ef 1,23; 3,6; 4,4.12; 5,23.30; Kol 1,18.24; 2,17.19; 3,15 .

40. Rom 8,10; 2 Kor 5,17; 13,5; Gal 2,20; 3,27-28; Fil 3,9.

41. Her tænker jeg eksempelvis på danske Johanne Stubbe Teglbjærg Kristensen, svenske Ola Sigurdson, tyske Bernd Wannenwetsch, britiske Sarah Coakley, britiske Graham Ward og amerikanske William T. Cavanaugh.

42. Jan Eckerdal, Folkkyrkans kropp. Einar Billings ecklesiologi i postsekulär belysning (Skellefteå: Artos 2012), 257. 
God is doing in human history." ${ }^{33}$ Det er desuden vigtigt at bemærke, at en krop er afgrænset. Kirken er altså en særlig social størrelse, som i én forstand er afsluttet i verden. Dermed kan udtrykket kirkens kropslighed på gunstig vis udtrykke kirken som en sarlig social størrelse.

$\mathrm{Nu}$ er kirken imidlertid en heterogen størrelse. Desuden er den som en social realitet uløseligt forbundet med andre sociale realiter, og dens grænser kan vanskeligt konciperes. Eksempelvis er kirke og samfund på kompleks vis viklet ind i hinanden. Derfor har den svenske teolog Ola Sigurdson inspireret af den russiske semiotiker Mikhail Bakhtin præsenteret udtrykket grotesk kropslighed. Den groteske krop er altid i sin vorden, flettet ind i andre kroppe og overskridende sine grænser. ${ }^{44}$ Den danske teolog Filip O. Bodilsen refererer Sigurdsons synspunkt således:

Kirkens sociale kropslighed er konstitueret ikke så meget intersubjektivt som interkorporativt, ikke så meget qua relationen mellem individer som qua relationen til andre sociale realiteter. Kristne tilhører eller participerer i en mangfoldighed af sociale sfærer (for eksempel familie, nabolag, arbejdsplads, forening, menighed), og kristen eksistens influeres af alle disse sfærer, ligesom kristen eksistens selv influerer andre sociale rum. ${ }^{45}$

Efter min mening kan udtryk som kropslighed og endog grotesk kropslighed være nyttige, når kirkens liv $\mathrm{i}$ et pluralistisk samfund skal begrebsliggøres. ${ }^{46}$

Udtrykket kirkens kropslighed må dog ikke blive et redskab til alene at forstå kirkens sociale liv i verden. Det er nemlig afgørende ikke blot at tilgå kirken som en historisk-empirisk størrelse, men også ud fra et teologisk-dogmatisk perspektiv. Derfor må der tages et teologisk forbehold over for en kropsterminologi, som alene har et socialt forklaringspotentiale. I så fald må kropsforståelsen udvides. Dette kan gøres på flere måder. Eksempelvis kan det gøres ved at anføre, at kirken ikke blot kan betragtes som en krop og endog en grotesk krop, men også en syg krop. Det er nemlig en krop, som bærer på en sygdom til døden, og som derfor har brug for helbredelse. Den amerikanske

43. Oliver O'Donovan, The Desire of the Nations: Rediscovering the Roots of Political Theology (Cambridge: Cambridge University Press 1996), 2.

44. Ola Sigurdson, Himmelska kroppar. Inkarnation, blick, kroppslighet (Göteborg: Glänta Produktion 2006), 379-380.

45. Filip O. Bodilsen, "Postsekulær politisk ekklesiologi. Forestillinger om kirkens offentlighedsdimension”, DTTK 41 (2014), 198 (kursiveringer originale).

46. Hermed bevæger man sig i øvrigt hen imod eller rettere tilbage til en forståelse, som i visse henseender minder meget om Augustins tale om to byer, da han også anser disse byer som viklet ind i hinanden. 
teolog William Cavanaugh udtrykker dette på en fin måde, når han skriver: "What the church makes visible is the whole dynamic drama of sin and salvation, not only the end result of a humanity purified and unified." ${ }^{77}$ I forlængelse af dette kan det anføres, at netop ved forvaltningen af nadveren fremstår kirken som en socialitet sui generis, og netop ved denne sakramentsforvaltning tilbydes en kur mod sygdommen til døden. I nadveren modtager kristne Kristus og inkorporeres i Kristi krop. Dermed forstås kirken ikke blot ud fra et sociologisk, men også ud fra et soteriologisk perspektiv. Udtrykket kirkens kropslighed kan således med dets teologisk-dogmatiske fundering og med nyere socialt orienterede begrebsudviklingstiltag udgøre et potentiale for en ekklesiologisk sammentænkning af empirisk virkelighed og dogmatisk refleksion af relevans for de nordiske folkekirker af i dag. ${ }^{48}$

\section{Konklusion}

Denne artikel har påvist en særpræget sammentænkning af folk og kirke i Danmark, Norge og Sverige fra det sekstende og op i det tyvende århundrede. Med henvisning til både historisk-empirisk virkelighed og teologisk-dogmatisk refleksion er der dernæst blevet argumenteret for nødvendigheden af en tydeligere artikulering af en teologi om kirken som en særlig social størrelse i senmoderne pluralistiske nordiske samfund. Siden oplysningstiden er den kirkelige hegemoni blevet gradvist opløst i de nordiske lande. Det er således en stor udfordring for de nordiske folkekirker at finde deres rolle i de nordiske samfund, som de tager sig ud i det enogtyvende århundrede. Dette fordrer en udvikling af en ekklesiologi, som ikke afspejler en

47. William T. Cavanaugh, Migrations of the Holy: God, State, and the Political Meaning of the Church (Grand Rapids: Eerdmans 2011), 162.

48. Hermed er altså blot antydet et potentiale. Dette er i en nordisk sammenhæng til dels forløst; se Jan Eckerdal, Folkkyrkans kropp. Einar Billings ecklesiologi i postsekulär belysning (Skellefteå: Artos 2012); Ola Sigurdson, Himmelska kroppar. Inkarnation, blick, kroppslighet (Göteborg: Glänta Produktion 2006); Kirsten Busch Nielsen \& Johanne Stubbe Teglbjærg (red.), Kroppens teologi - teologiens krop (København: Anis 2011); det første bidrag relaterer sig til dels til den specifikke ekklesiologiske udfordring, som denne artikel tydeliggør, mens de to sidste bidrag ikke gør det i samme grad. De seneste år har den britiske teolog Paul Fiddes og den amerikanske teolog Christian Scharen sammen med netværket Ecclesiology and Ethnography i øvrigt bidraget til en empirisk vending inden for ekklesiologi, som har gjort op med en ensidig dogmatisk tilgang til ekklesiologi; i dag synes mange dog at ville forene en historisk-empirisk og en teologisk-dogmatisk tilgang til forståelsen af den kristne kirke. 
kirkelig og en samfundsmæssig situation, som ikke længere eksisterer. I forlængelse af dette har jeg peget på kirkens kropslighed som et nyttigt udtryk i denne situation, da dette udtryk - i det mindste som den er fremstillet i denne artikel - præsenterer en forståelse af kirken som værende en særlig social størrelse, samtidig med at kirken som social realitet altid er i sin vorden, overskridende sine grænser og flettet ind i andre socialiteter. På denne måde må de nordiske folkekirker "forstås som kirker, der på den ene side er vævet ind i og spiller en væsentlig rolle [...i de nordiske samfund...], og som på den anden side fremstår som en del af en afgrænset religiøs tradition, der ikke kan stå for hvad som helst." ${ }^{\prime 9}$ Kirken må anerkende, at den er indfældet i samfundet, og lade sin egenart være konstituerende for en åbenhed over for, et ansvar for og et engagement i samfundet. ${ }^{50} \mathrm{I}$ et pluralistisk samfund vil kirken på flere måder være forskellig fra det samfund, som den er en del af. Står kirken i denne situation ved sin egenart, åbner det op for betydningsfulde muligheder for, at de nordiske folkekirker kan bidrage selvstændigt til de nordiske samfund. ${ }^{51}$

49. Jeppe Bach Nikolajsen, "Folkekirken som ledende trossamfund. Folk og kirke er ikke længere ét og det samme", KD den 16. april 2015.

50. Jf. Jeppe Bach Nikolajsen, "Kirkens rolle i et pluralistisk samfund", DTTK 42 (2015), 22.

51. Afslutningsvist vil jeg gerne takke Simon Schmidt og Kurt E. Larsen for kritisk gennemlæsning af et udkast til denne artikel. 